\title{
Analisis Ukuran Butir Sedimen di Perairan Muara Sungai Kali Bodri, Kecamatan Patebon, Kabupaten Kendal
}

\author{
Afidyah Vicky Antari ${ }^{1 *}$, Agus Anugroho Dwi Suryoputro ${ }^{1}$, Warsito Atmodjo ${ }^{1}$, Heryoso Setiyono ${ }^{1}$, \\ Lilik Maslukah ${ }^{1}$ \\ ${ }^{3}$ Departemen Oseanografi, Fakultas Perikanan dan Ilmu Kelautan, Universitas Diponegoro \\ Jl. Prof. H. Sudarto, SH, Tembalang, Semarang, 50275 \\ Email: *afidyahvickyantari2@gmail.com
}

\begin{abstract}
Abstrak
Muara Sungai Kali Bodri merupakan jalur lalu lintas kapal yang penting bagi nelayan pantura. Besarnya tingkat sedimentasi yang membentuk gosong pasir di depan muara sungai berpotensi menghambat keluar masuknya kapal ke Sungai Kali Bodri. Tujuan penelitian adalah untuk mengetahui distribusi ukuran butir sedimen di perairan Muara Sungai Kali Bodri periode Agustus 2019. Metode kualitatif dengan tipe studi kasus digunakan dalam penelitian ini. Hasil penelitian menyatakan bahwa pada bulan Agustus 2019 distribusi sedimen di perairan Muara Sungai Kali Bodri berupa gosong pasir di sebelah Utara dan Timur muara sungai dengan pola gosong pasir sejajar dengan garis pantai. Terdapat dua tipe sedimen di perairan Muara Sungai Kali Bodri yaitu pasir dan lanau. Faktor hidro-oseanografi yang mempengaruhi distribusi sedimen di Muara Sungai Kali Bodri berupa debit sungai 4,091 1/det; inputan sedimen tersuspensi 0,0217 $\mathrm{m}^{3}$ /hari; MSL 0,873 m; LLWL 0,241 m; HHWL 1,506 m; kedalaman perairan (-0,01) m sampai (-13) m; kecepatan arus $(0,004$ sampai 4,042$) \mathrm{m} / \mathrm{det}$; arah arus utara $\left(212,3^{\circ}-270^{\circ}\right)$ timur; tinggi gelombang $(0,006-0,163) \mathrm{m}$; dan arah gelombang utara $7^{\circ}$ timur. Faktor oseanografi yang dominan mempengaruhi distribusi sedimen Muara Sungai Kali Bodri adalah energi gelombang.
\end{abstract}

Kata kunci : Muara Sungai, Distribusi Sedimen, Analisis Granulometri, Sungai Kali Bodri Kendal

\section{Abstract}

Kali Bodri River estuary is an important boat traffic lane for pantura fishermen. The amount of sedimentation that forms sandbar in front of river mouths has the potential to inhibit the entry and exit of ships into the Kali Bodri River. The purpose of this study was to determine the size distribution of sediment in the waters of the Kali Bodri River in the August 2019 period. A qualitative method with the case study type was used in this study. The results of the study stated that in August 2019 the distribution of sediments in the waters of the Kali Bodri River in the form of the sandbar to the north and east of the river mouth with sandbar patterns parallel to the coastline. There are two types of sediments in the waters of the Kali Bodri River, sand and silt. Hydro-oceanographic factors affecting the distribution of sediments in the Kali Bodri River estuary is the river discharge 4,091 l/sec; input of suspended sediment $0.0217 \mathrm{~m}^{3} /$ day; MSL $0.873 \mathrm{~m}$; LLWL $0.241 \mathrm{~m}$; HHWL $1.506 \mathrm{~m}$; water depths (-0.01 to -13) $\mathrm{m}$; current speed (0.004 to 4,042) m/sec; current direction North $\left(212.3^{\circ}-270^{\circ}\right)$ East; wave height (0.006 - 0.163) $\mathrm{m}$; and the wave direction North $7^{\circ}$ East. The dominant oceanographic factor affecting the distribution of the Kali Bodri River sediment is a wave energy.

Keywords : Estuary, Sediment Distribution, Granulometry Analysis, Kali Bodri Kendal River

\section{PENDAHULUAN}

Kendal memiliki satu sungai besar yang berada di wilayah Kecamatan Patebon yaitu Sungai Kali Bodri (Wijaya et al., 2014). Banyaknya masukan sedimen dari aliran Sungai Kali Bodri menyebabkan terjadinya pendangkalan di sekitar Muara Sungai Kali Bodri. Pendangkalan muara sungai juga dipengaruhi oleh pasang surut, arus, dan gelombang. Sedimen terbawa dari laut lepas pada saat pasang dan terendapkan di sekitar muara pada saat surut. Sedimen yang terendapkan tersebut menyebabkan adanya perubahan morfologi muara setiap tahunnya.

Analisis ukuran butir sedimen dilakukan untuk menentukan tipe sedimen dan persebarannya, juga dapat digunakan untuk mengetahui dinamika dan energi di lingkungan pengendapannya (Stewart, 1958). 
Menurut Triatmodjo (1999), sebaran ukuran butir sedimen di muara sungai dapat berupa gosong pasir sejajar mulut sungai, gosong pasir sejajar garis pantai, atau sedimen yang menyebar ke arah laut lepas. Sebaran ukuran butir sedimen di muara sungai dipengaruhi oleh masukan sedimen dari sungai terhadap energi dari lautan yang paling dominan. Energi laut yang dominan dapat berupa energi gelombang, energi arus, atau energi pasang surut. Oleh karena itu, dalam penentuan distribusi ukuran butir sedimen diperlukan analisis terkait hubungan antara ukuran butir sedimen dengan faktor oseanografi yang mempengaruhinya.

Siswanto (2007), yang mengkaji sebaran sedimen dengan menggunakan analisis ukuran butir di Muara Sungai Kali Bodri menyatakan bahwa di depan muara sungai, persentase sedimen jenis pasir memberikan nilai yang lebih kecil dibanding persentase sedimen pasir yang mendekati bibir muara. Hal ini menunjukkan bahwa pada tahun 2007, sedimentasi tinggi berlokasi di kedua sisi muara yang menyebabkan semakin majunya posisi mulut muara. Atmodjo (2010), menyatakan bahwa terdapat dua gosong pasir di depan mulut Muara Sungai Kali Bodri, dengan gosong pasir di sebelah barat lebih besar dari gosong pasir sebelah timur. Gosong pasir ini menjadi satu dengan masing-masing kedua mulut muara pada saat surut di malam hari sedangkan pada saat pasang di siang hari gosong pasir tersebut kembali terpisahkan oleh air laut.

Menurut Triatmodjo (1999), morfologi muara sungai terbentuk berdasarkan faktor dominan yang mempengaruhinya. Faktor yang mempengaruhi pembentukan morfologi muara sungai yaitu pasang surut, gelombang, dan debit sungai. Menurut Atmodjo (2010), perubahan morfologi Muara Sungai Kali Bodri dominan dipengaruhi oleh energi gelombang yang relatif besar sehingga setiap tahunnya gosong pasir di depan muara sungai semakin lebar. Keberadaan gosong ini jika terus dibiarkan maka akan memberikan dampak terhadap kegiatan penduduk terutama nelayan yang kesulitan dalam akses keluar masuk Sungai Kali Bodri. Dengan demikian maka perlu kajian lebih lanjut mengenai ukuran butir sedimen di Muara Sungai Kali Bodri pada saat ini dan faktor oseanografi yang mempengaruhinya.

Penelitian ini bertujuan untuk mengetahui distribusi ukuran butir sedimen dan menentukan faktor dominan yang berpengaruh terhadap distribusi ukuran butir sedimen di perairan Muara Sungai Kali Bodri pada periode 2019.

\section{MATERI DAN METODE}

Materi penelitian meliputi pasang surut, gelombang, arus, data debit sungai, material padatan tersuspensi, dan topografi dasar perairan. Penelitian ini dilakukan di perairan Muara Sungai Kali Bodri, Kecamatan Patebon, Kabupaten Kendal pada tanggal 25 - 27 Agustus 2019 dengan lokasi penelitian berada pada koordinat $6^{\circ} 49^{\prime} 14.86^{\prime}$ ' $-6^{\circ} 51^{\prime} 22.54$ ' LS dan $110^{\circ} 9^{\prime} 26.48^{\prime \prime}-110^{\circ} 11$ '32.71' ' BT.
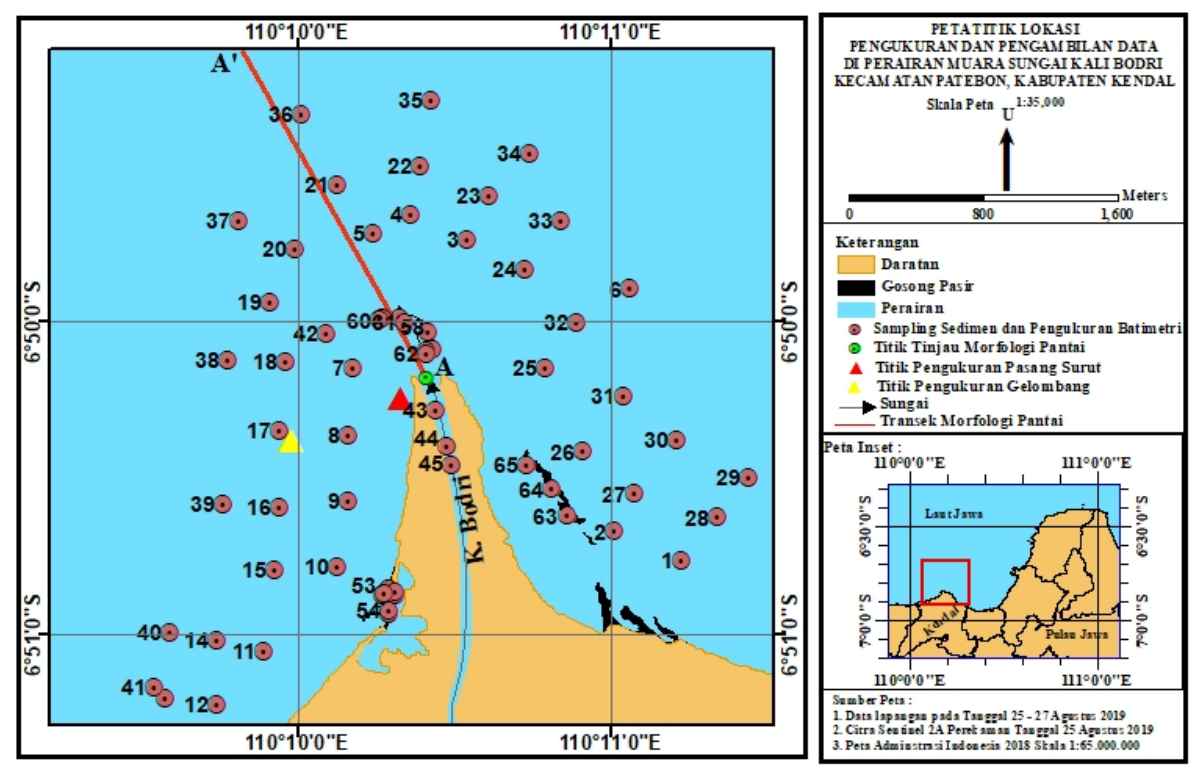

Gambar 1. Peta lokasi pengukuran dan pengambilan data 
Metode penelitian yang digunakan adalah adalah metode kualitatif dengan tipe studi kasus. Penentuan titik sampling dilakukan dengan metode stratified purposive sampling dengan titik sampling sebanyak 65 titik. Sebaran titik lokasi pengambilan data mulai dari muara sungai menyebar kearah kiri dan kanan muara sungai, di perairan delta dan perairan laut dapat dilihat pada peta Gambar 1 . Pertimbangan pengambilan titik lokasi tersebut didasarkan pada asumsi bahwa debit sedimen yang berasal dari sungai akan menyebar ke segala arah yaitu arah ke kiri dan ke arah kanan dari muara sungai (Atmodjo, 2010). Data arus dan gelombang dilakukan perekaman dengan instrumen ADCP (Accoustic Doppler Current Profiler) selama 3 hari pada tanggal 25 - 27 Agustus 2019. Analisis data meliputi analisis statistik granulometri sedimen, analisis energi pengendapan berdasarkan kecepatan dan arah arus serta tinggi dan arah gelombang.

\section{HASIL DAN PEMBAHASAN}

\section{Pasang Surut}

Hasil dari pengolahan data pengukuran lapangan pasang surut bulan Agustus 2019 menggunakan metode Admiralty didapatkan nilai elevasi muka air laut berupa MSL sebesar 0,873 m, Z0 sebesar 0,633 $\mathrm{m}$, HHWL sebesar 1,506 m, MHWL sebesar 0,779 m, LLWL sebesar 0,241 m, dan MLWL sebesar $0,453 \mathrm{~m}$. Tipe pasang surut perairan sekitar Muara Sungai Kali Bodri adalah pasang surut campuran condong harian tunggal dengan nilai formzahl sebesar 2,283. Hal ini didukung oleh penelitian sebelumnya. Siregar et al. (2014) menyatakan bahwa pasang surut pada perairan Kendal memiliki tipe campuran condong harian tunggal dengan nilai formzahl sebesar 1,978. Penelitian lain yang mendukung pernyataan ini yaitu Srijati et al. (2017) yang menyatakan bahwa pasang surut perairan Kendal memiliki tipe pasang surut campuran (dominan tunggal) dengan nilai formzahl sebesar 1,57. Kondisi pasang surut pada lokasi penelitian tidak begitu signifikan untuk mempengaruhi jenis dan sebaran ukuran butir sedimen karena tenaga yang dihasilkan oleh pasang surut berpotensi kecil untuk memindahkan partikel sedimen.

\section{Morfologi Pantai}

Hasil penelitian menunjukkan bahwa pantai di Muara Sungai Kali Bodri berbentuk Cuspate dengan nilai kedalaman perairan terkoreksi berkisar antara $0,1-13 \mathrm{~m}$. Hal ini didukung dengan pernyataan Sanjoto et al. (2012) yang menyatakan bahwa pada tahun 1910 Muara Sungai Kali Bodri memiliki bentuk delta runcing (cuspate) namun pada tahun 2009 mengalami perubahan bentuk menjadi delta tumpul (lobate). Lumbanbatu (2009) mengindikasikan adanya dorongan tenaga run off sungai yang besar sehingga mengubah bentuk pantai yang semula runcing menjadi tumpul. Pada tahun 2019, bentuk Muara Sungai Bodri kembali menjadi bentuk runcing. Perubahan tersebut kemungkinan disebabkan karena pada tahun 2010 - 2019 tenaga dari laut lebih dominan dalam mempengaruhi adanya akresi dan abrasi pantai di sekitar Muara Sungai Kali Bodri. Hal ini didukung oleh pernyataan Hehanusa et al. (1975) yang menyebutkan bahwa delta berbentuk cuspate terbentuk akibat proses marin yang lebih kuat dibanding proses sungai sehingga delta jenis ini termasuk high-destructive deltas.

Pada Gambar 7, pola kontur batimetri yang terbentuk sejajar dengan garis pantai dan tidak terdapat kurva - kurva tertutup pada kontur batimetri sehingga dapat disimpulkan bahwa morfologi dasar perairan Muara Sungai Kali Bodri relatif rata. Pada penampang melintang morfologi perairan (Gambar 2) menunjukkan adanya gosong pasir diantara mulut sungai hingga kedalaman $1 \mathrm{~m}$. Daerah mulut sungai memiliki kelerengan 0,381\% (Segmen A). Gosong pasir memiliki lebar $6 \mathrm{~m}$ dengan bentuk yang cembung kearah laut. Daerah dimulai dari gosong terluar kearah laut lepas memiliki nilai kelerengan rerata sebesar 0,891\% (Segmen B, C dan D). Berdasarkan nilai kelerengan tersebut dapat disimpulkan bahwa kelerengan dasar laut perairan Muara Sungai Kali Bodri sangat landai. Hal ini didukung oleh pernyataan Supriyadi et al. (2014) yang menyebutkan bahwa pantai utara Jawa cenderung bertipe kelerengan landai yaitu antara $0-2 \%$. Supriyadi et al. (2014) juga menjelaskan bahwa kelerengan dasar laut yang landai dapat disebabkan beberapa faktor seperti kondisi perairan yang tenang, tinggi gelombang yang kecil dan jenis sedimen yang terbentuk. 


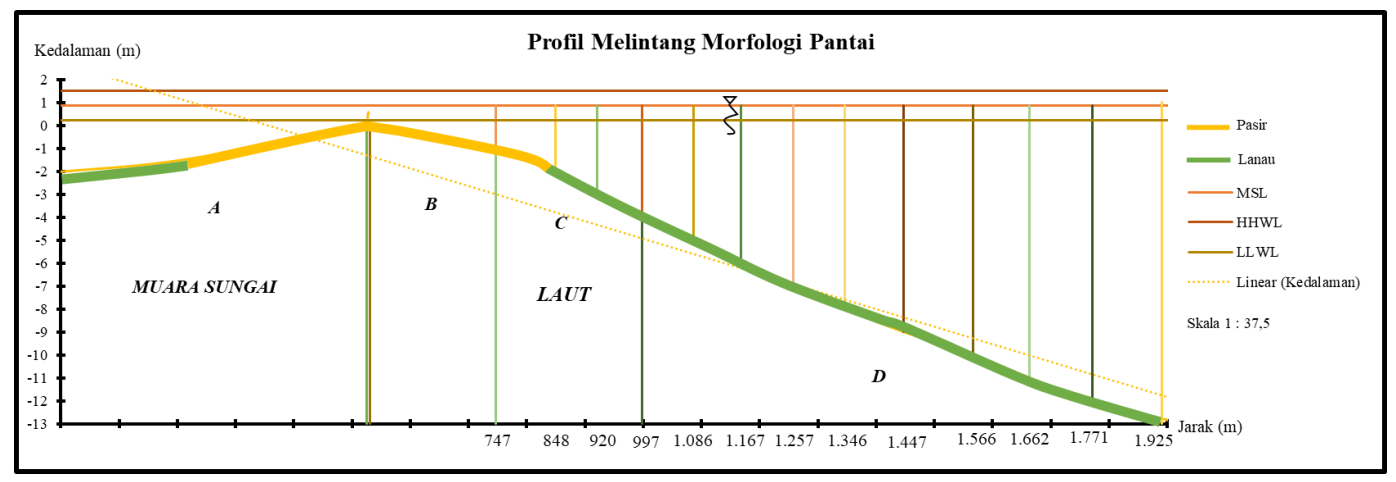

Gambar 2. Penampang Melintang Morfologi Dasar Perairan Muara Sungai Kali Bodri

\section{Faktor Hidro-oseanografi}

Hasil perhitungan arah dan kecepatan arus menunjukkan nilai kecepatan maksimum sebesar 4,042 $\mathrm{m} /$ det menuju $212,3 \mathrm{~N}^{\mathrm{o}} \mathrm{E}$ dan kecepatan arus minimum sebesar $0,004 \mathrm{~m} /$ det menuju $270 \mathrm{~N}^{\circ} \mathrm{E}$ yang ditunjukkan pada Tabel 1 dan scatter plot yang menunjukkan nilai kecepatan di komponen u dan v pada kedalaman 0.8d ditunjukkan pada Gambar 3. Berdasarkan hasil pengolahan data arus menggunakan $\mathrm{Wr}$. Plot View didapatkan arah arus dominan yang ditunjukkan pada Gambar 4. Arah arus dominan bergerak kearah Utara dengan kecepatan $0,00-0,24 \mathrm{~m} /$ det dan kearah Tenggara dengan kecepatan 0,06-0,12 $\mathrm{m} /$ det. Kecepatan arus maksimum bergerak kearah Timur. Arah arus yang didapatkan dari hasil mawar arus membuktikan bahwa arus yang bergerak di perairan sekitar Muara Sungai Kali Bodri bergerak kearah utara dan tenggara sesuai dengan arah pada scatter plot.

Tabel 1. Kecepatan dan Arah Arus Maksimum dan Minimum

\begin{tabular}{ccccc}
\hline Kedalaman & $\begin{array}{c}\text { Kecepatan Arus } \\
\text { Maksimum } \\
(\mathrm{m} / \mathrm{det})\end{array}$ & $\begin{array}{c}\text { Arah } \\
\left(\mathrm{N}^{\circ} \mathrm{E}\right)\end{array}$ & $\begin{array}{c}\text { Kecepatan Arus } \\
\text { Minimum } \\
(\mathrm{m} / \mathrm{det})\end{array}$ & $\begin{array}{c}\text { Arah } \\
\left(\mathrm{N}^{\circ} \mathrm{E}\right)\end{array}$ \\
\hline $0.8 \mathrm{~d}$ & 4.042 & 212.3 & 0.004 & 270 \\
\hline
\end{tabular}

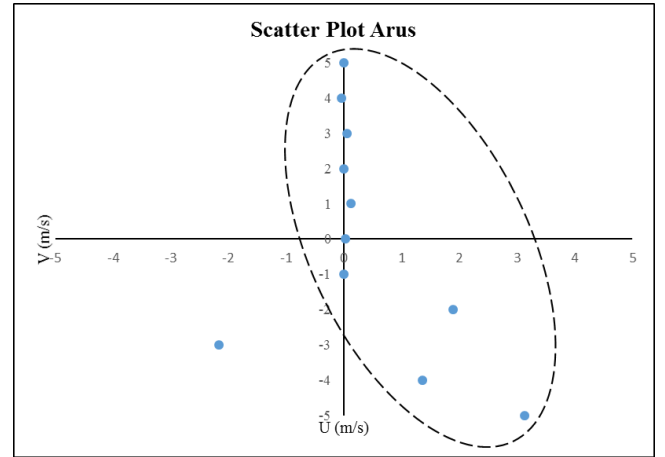

Gambar 3. Scatter plot arus

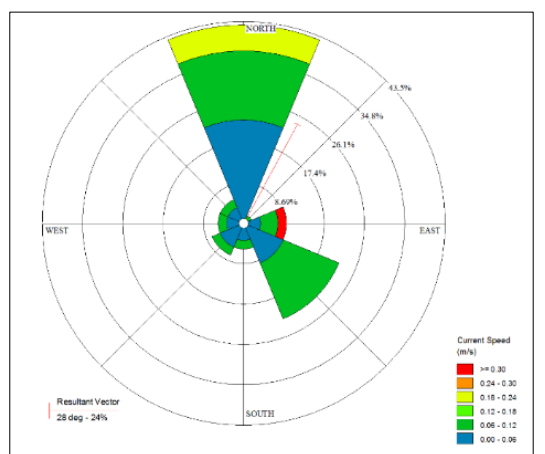

Gambar 4. Mawar arus

Pada hasil current rose yang ditunjukkan pada Gambar 4 menunjukkan bahwa arus dominan bergerak dari arah Utara ke Tenggara begitupun sebaliknya dengan nilai resultan dari arah Timur Laut sebesar $51 \mathrm{~N}^{0} \mathrm{E}$. Angin yang berasal dari Utara menimbulkan gelombang dan arus dominan dari arah Utara ke Selatan. Namun pada saat mendekati muara terjadi deformasi yang menyebabkan gelombang dan arus mengalami pembelokan. Arus pasang surut ini mempengaruhi sebaran sedimen diperairan dan ketika suatu wilayah mendapatkan efek gelombang yang besar maka arus di wilayah tersebut melemah. Kondisi arus yang tenang menyebabkan material sedimen tersuspensi mudah mengendap hal ini ditunjukkan dengan tingginya sedimentasi dimuara sungai. Hal ini sesuai dengan pendapat Wisha et al. (2017) yang menyebutkan bahwa dinamika massa air yang bergerak bolak-balik menyebabkan transpor 
bahan organik maupun sedimen menjadi lebih baik, dan di beberapa wilayah yang dilewati arus lemah akan terjadi penumpukkan sedimen dan bahan organik tersebut. Berdasarkan muatan sedimen tersuspensi dari darat didapatkan nilai debit suspended sedimen rerata pada tanggal 25 - 27 Agustus 2019 sebesar $0,0217 \mathrm{~m}^{3} /$ hari. Kecepatan arus yang lemah ini menyebabkan sedimen yang berasal dari sungai mengendap tidak jauh didepan mulut muara terutama untuk sedimen pasir yang memiliki massa lebih besar. Hal ini sesuai dengan pendapat Wisha et al. (2017) yang menyebutkan bahwa arus yang lemah menyebabkan sedimen yang teraduk mudah mengendap.

Pengukuran gelombang lapangan dengan menggunakan ADCP menunjukkan tinggi $(H)$ dan periode $(T)$ gelombang. Berdasarkan data tersebut, diperoleh nilai $H$ maksimum yaitu $0,163 \mathrm{~m}, H$ minimum yaitu $0,006 \mathrm{~m}, H$ signifikan $0,123 \mathrm{~m}$ dan $H$ rerata $0,102 \mathrm{~m}$ dengan nilai $T$ maksimum sebesar 6,5 detik, $T$ minimum 2,1 detik, $T$ signifikan 4,66 detik dan $T$ rerata 3,1 detik. Setelah didapatkan nilai fetch efektif untuk pembangkitan gelombang di Perairan Muara Sungai Kali Bodri berasal dari arah Utara sepanjang $175.713 \mathrm{~km}$ dan Timur Laut sepanjang $129.456 \mathrm{~km}$ dilakukan peramalan gelombang dengan metode SMB Kemudian didapatkan hasil peramalan $H$ signifikan sebesar 0,645 m dan $T$ signifikan sebesar 4,254 detik pada Bulan Agustus 2019. Berdasarkan tinggi gelombang signifikan (Hs) dan periode gelombang signifikan (Ts) didapatkan $\mathrm{d} / \mathrm{L}$ sebesar 0,131 . Sesuai dengan pernyataan Triatmodjo (1999) bahwa gelombang yang memiliki kedalaman $0,05<\mathrm{d} / \mathrm{L}<0,5$ termasuk dalam gelombang perairan menengah atau transisi sehingga gelombang yang terjadi di Perairan Muara Sungai Kali Bodri memiliki karakteristik yang dipengaruhi oleh angin dengan tinggi gelombang pada musim timur relatif kecil dan periode gelombang yang singkat. Hal ini diperkuat oleh pernyataan Handoyo dan Suryoputro (2015) yang menyatakan bahwa tinggi gelombang di perairan pantai Kendal dapat dikategorikan kecil hal ini dimungkinkan karena angin yang berhembus yang relatif kecil. Adapun mawar angin yang menggambarkan arah angin dominan dan arah resultan ditunjukkan pada Gambar 5 dan Gambar 6.

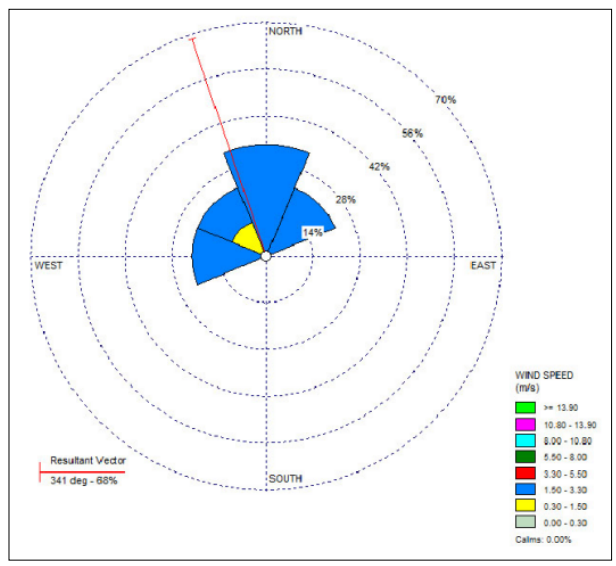

Gambar 5. Mawar angin tanggal $25-27$ Agustus 2019 arah resultan utara $\left(\mathrm{N} 341^{\circ} \mathrm{E}\right)$

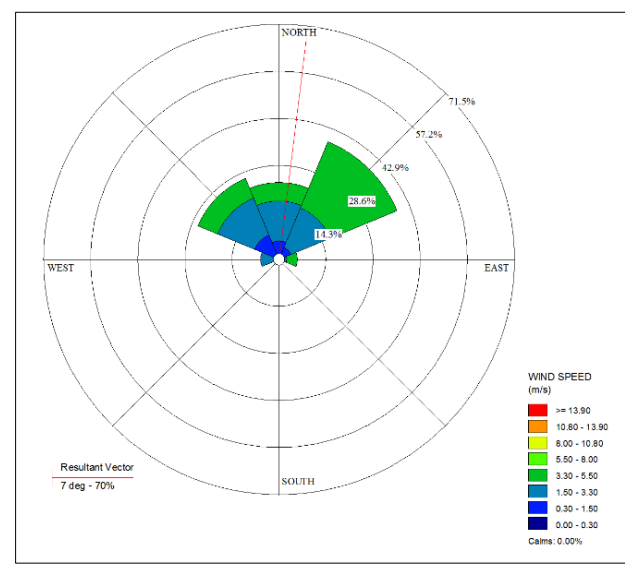

Gambar 6. Mawar angin Bulan Agustus 2019 arah resultan $\left(\mathrm{N} 7^{\circ} \mathrm{E}\right)$

Berdasarkan hasil perhitungan gelombang pecah menggunakan data peramalan diketahui bahwa tinggi gelombang pecah sebesar $0,655 \mathrm{~m}$ yang berarti gelombang pecah tertinggi berada tepat di depan mulut muara sungai. Gelombang pecah pada daerah ini lebih tinggi dibanding daerah timur maupun barat karena angin dominan berasal dari arah utara sehingga kecepatan angin pada daerah ini tidak terhalang oleh apapun. Ketinggian gelombang pecah ini juga dipengaruhi oleh pendangkalan perairan. Hal ini didukung dengan pernyataan Sakka et al. (2010) yang menyebutkan bahwa pantai dengan kelerengan landai memiliki gelombang yang lebih tinggi daripada pantai yang curam. Gelombang yang datang dari arah utara menuju mulut muara bergerak dengan cepat kemudian pada saat akan pecah gelombang menabrak dasar perairan sehingga gelombang akan berubah bentuk dan ketinggian puncak gelombang akan bertambah pada saat pecah. Hal ini sesuai dengan pernyataan Siregar et al. (2014) yang menyebutkan bahwa gelombang yang datang menuju pantai akan mengalami refraksi yaitu perubahan bentuk sebagai akibat adanya perubahan kedalaman perairan. 
Pada bagian timur muara sungai nilai ketinggian gelombang pecah tidak jauh berbeda dengan ketinggian gelombang pecah di depan muara sungai yaitu sebesar $0,621 \mathrm{~m}$. Hal ini dibuktikan dengan adanya gosong pasir sejajar pantai di sebelah timur Muara Sungai Kali Bodri. Triatmodjo (1999) menyebutkan bahwa sedimen gosong pasir sejajar pantai menandakan bahwa sedimentasi di daerah tersebut lebih dominan dipengaruhi oleh energi gelombang. Gosong yang posisinya sejajar pantai ini dipengaruhi oleh perubahan arah gelombang yang disebabkan oleh perubahan kedalaman sehingga gelombang datang dari arah utara berubah arah ke arah barat daya ketika mendekati pantai sehingga arah datang gelombang membentuk sudut tegak lurus garis pantai. Hal ini diperkuat oleh pernyataan (Sakka et al., 2010) yang menyebutkan bahwa perubahan arah datang gelombang terjadi pada saat gelombang sudah dekat pantai. Perubahan ini disebabkan oleh pengaruh refraksi karena adanya perbedaan kecepatan rambat gelombang. Perbedaan cepat rambat gelombang bergerak membentuk sudut terhadap garis pantai. Hal ini menyebabkan sedimen yang terbawa oleh gelombang berkumpul di daerah timur dan posisinya menjadi sejajar dengan garis pantai. Sudut gelombang pecah pada daerah penelitian memiliki nilai sebesar $19,225^{\circ}$. Hal ini sesuai dengan pernyataan Triatmodjo (1990) yang menyatakan bahwa arus sepanjang pantai dapat terbentuk apabila sudut datang gelombang pecah lebih dari $5^{\circ}$. Dari hasil besar sudut gelombang pecah didapat nilai kecepatan longshore current sebesar $0,8926 \mathrm{~m} /$ det. Arah datang gelombang dapat mempengaruhi energi gelombang dan kecepatan arus sepanjang pantai. Ketika arah datang gelombang tegak lurus dengan garis pantai, maka energi gelombang lebih dominan. Sedangkan untuk arus sejajar pantai, kecepatannya akan melemah ketika arah datangnya hampir tegak lurus dengan garis pantai. Arus sejajar pantai yang bergerak dari tenggara ke utara dengan kecepatan 1,0045 $\mathrm{m} /$ det mengangkut sedimen dan bertemu dengan gelombang yang berasal dari timur laut menyebabkan berkurangnya kecepatan arus sepanjang pantai dan partikel sedimen terendapkan pada daerah gosong pasir di timur Muara Sungai Kali Bodri. Sebagian kecil partikel sedimen digosong timur muara sungai yang terbawa arus sepanjang pantai kearah utara kemudian berbelok kearah barat karena bertabrakan dengan gelombang yang datang dari arah $\mathrm{U} 7^{\circ} \mathrm{T}$ kemudian mengendap di daerah gosong depan muara karena kecepatan longshore current berkurang. Hal ini yang mengakibatkan bentuk gosong pasir di depan muara seperti berbelok kearah barat karena ada masukkan sedimen dari arah timur muara sungai. Hal ini diperkuat oleh Komar (1998) yang menyatakan bahwa terbentuknya sudut datang gelombang akan mempengaruhi nilai arus sejajar pantai dimana dapat memungkinkan sedimen dasar berpindah sepanjang pantai dan terendapkan pada daerah dimana kecepatan arus tidak mampu lagi untuk memindahkan sedimen.

\section{Sedimen}

Partikel sedimen yang berada di Muara Sungai Kali Bodri berasal dari darat dan dari laut lepas. Gemilang et al. (2018), menyebutkan bahwa perbedaan ukuran butir sedimen menunjukkan asal sumber sedimen. Ukuran butir juga merupakan indikasi besar atau kuatnya kekuatan arus dan gelombang yang bekerja pada lingkungan pengendapan tersebut (Rifardi et al., 1998). Berdasarkan hasil pengolahan data dari 65 sampel sedimen menggunakan analisis granulometri disimpulkan bahwa secara umum material sedimen yang berada di Perairan Muara Sungai Kali Bodri merupakan fraksi pasir dan lanau dengan pola sebaran yang sejajar dengan garis pantai. Hal ini didukung dengan pernyataan Triatmodjo (1999) dalam Siregar et al. (2014) bahwa sebagian besar pantai utara Jawa dan timur Sumatera merupakan pantai berjenis lumpur dan pasir. Sebaran ukuran butir sedimen di Muara Sungai Kali bodri menunjukkan bahwa semakin kearah darat, partikel sedimen semakin kasar. Pada peta pola sebaran sedimen (Gambar 7), sedimen pasir tersebar dekat dengan pesisir pantai yaitu berada antara kedalaman $0-3 \mathrm{~m}$ karena sedimen yang memiliki ukuran butir lebih besar akan mengendap di perairan dengan cepat. Sedimen yang berasal dari darat masuk ke muara melalui aliran Sungai Kali Bodri dan bertemu dengan masukan sedimen dari laut yang ditranspor oleh tenaga gelombang. Sedimen ini berkumpul di depan muara sungai membentuk kenampakan baru berupa gosong pasir. Hal ini sesuai dengan pendapat Gemilang et al. (2018), yang menyebutkan bahwa disaat kondisi pasang arus sungai yang bertemu dengan air laut akan melemah di bagian muara sehingga endapan sungai laut bercampur dengan fraksi sedimen kasar. Sedangkan sedimen lanau berada di daerah yang lebih jauh dari pesisir yaitu berada pada kedalaman $>3 \mathrm{~m}$ karena material dari sungai yang terakumulasi langsung mengalir menuju laut 
kemudian terbawa arus dan bercampur dengan sedimen yang berjenis pasir. Partikel yang lebih kecil terbawa oleh arus laut dan mengendap di laut lepas atau menjadi sedimen tersuspensi di kolom air. Dyer (1986) menyebutkan bahwa sedimen dengan ukuran yang lebih halus lebih mudah berpindah dan cenderung lebih cepat bergerak daripada ukuran kasar.

Hasil dari analisis granulometri berdasarkan klasifikasi parameter statistik ukuran butir menurut Folk dan Ward (1975) menunjukkan bahwa sedimen pasir memiliki nilai diameter ukuran butir sebesar $0,2447-0,9058 \mathrm{~mm}$ dan nilai sortasi dari $0,3004-1,3513$ yang berarti terpilah buruk hingga terpilah sangat baik, nilai skewness dari -0,1671 - 0,2558 yang berarti dari menceng kasar hingga menceng halus dan nilai kurtosis dari 0,5692 - 2,6752 yang berarti sangat platikurtik hingga sangat leptokurtik. Sedimen lanau ini memiliki diameter ukuran butir sebesar 0,0059 dengan nilai sortasi dari 0,3018 0,3063 yang berarti masuk kedalam klasifikasi terpilah sangat baik, nilai skewness $-0,0195--0,0190$ yang berarti masuk kedalam klasifikasi menceng simetris dan nilai kurtosis dari $0,7535-0,7545$ yang berarti masuk kedalam klasifikasi sangat platikurtik hingga platikurtik. Hasil analisis granulometri secara lengkap dapat dilihat pada Lampiran (Tabel 2). Berdasarkan hasil tersebut disimpulkan bahwa ukuran butir sedimen pasir lebih bervariasi dibandingkan dengan sedimen lanau jika dilihat dari rentang nilai sortasi, skewness, dan kurtosisnya. Variasi nilai ini menunjukkan bahwa kondisi sedimen di Muara Sungai Kali Bodri dipengaruhi oleh tenaga dari laut yang mengakibatkan tercampurnya ukuran partikel sedimen yang berbeda. Hal ini diperkuat dengan pernyataan Nugroho dan Basit (2014) yang menyebutkan bahwa perairan yang didominasi oleh pasir halus - kasar menunjukkan bahwa sedimen telah mengalami proses deposisi. Proses deposisi tersebut dicirikan dengan terendapkannya sedimen berukuran halus - kasar ditambah adanya pengaruh arus yang bekerja pada lingkungan tersebut yang mengakibatkan ukuran butir sedimen yang mengendap tercampur secara acak (Nugroho dan Basit, 2014).
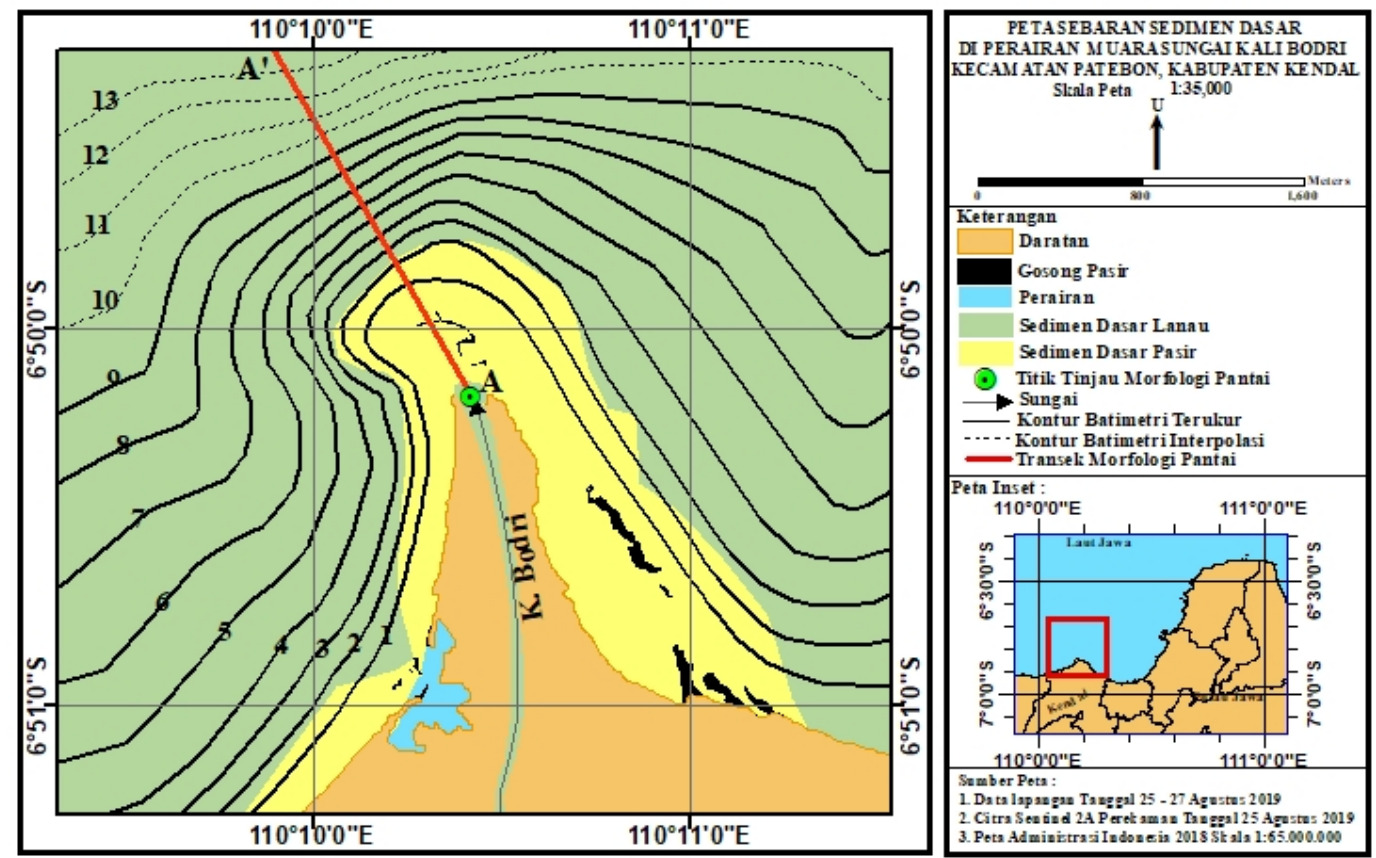

Gambar 7. Peta sebaran sedimen dasar

\section{KESIMPULAN}

Secara umum sedimen di perairan Muara Sungai Kali Bodri terdiri dari fraksi pasir dan lanau. Sedimen pasir tersebar di perairan dangkal yaitu pada kedalaman $0-3 \mathrm{~m}$ dan dominan berada didaerah utara Muara Sungai Kali Bodri dan sedimen lanau tersebar di dalam sungai dan di perairan dalam pada kedalaman $>3 \mathrm{~m}$ dan dominan berada di daerah barat dan timur Muara Sungai Kali Bodri. Sedimen yang berasal dari darat melalui aliran sungai bergerak ke arah laut lepas dan sedimen dari laut yang terbawa 
oleh gelombang dan arus sejajar pantai terendapkan didaerah perairan dangkal membentuk suatu kenampakan baru berupa gosong pasir di sebelah utara dan timur Muara Sungai Kali Bodri.

Faktor dominan yang mempengaruhi sebaran ukuran butir sedimen adalah energi gelombang. Hal ini dibuktikan dengan bentuk gosong pasir di utara muara sungai yang cembung ke arah laut dan dominasi sedimen kasar di perairan dangkal yang menandakan bahwa gelombang berpengaruh lebih besar dibandingkan debit sungai, arus, dan pasang surut.

\section{DAFTAR PUSTAKA}

Atmodjo, W., 2010. Sebaran Sedimen di Perairan Delta Sungai Bodri, Kendal, Jawa Tengah. Jurnal Ilmu Kelautan, 15(1): 53 - 58.

Dyer, K.R., 1986. Coastal and Estuary Sediment Dynamic. John Willey \& Sons. Chichester.

Folk, R.L. dan W.C. Ward., 1957. Brazos River Bar, a Study in the Significance of Grainsize Parameters. J. of Sedimentary Petrologi, 27: 3 - 26.

Gemilang, W.A., U.J. Wisha., G.A. Rahmawan., dan R. Dhiauddin., 2018. Karakteristik Sebaran Sedimen Pantai Utara Jawa Studi Kasus: Kecamatan Brebes Jawa Tengah. Jurnal Kelautan Nasional, 13(2): 65 - 74.

Handoyo, G dan Agus A.D Suryoputro., 2015. Kondisi Arus dan Gelombang pada Berbagai Kondisi Morfologi Pantai di Perairan Pantai Kendal Provinsi Jawa Tengah. Jurnal Kelautan Tropis, 18(1): $33-37$.

Hehanusa, P.E., S. Hadiwisastra dan S. Djoehanah., 1975. Sedimentari Delta Baru Cimanuk. Geologi Indonesia, 3(11): $21-35$

Lumbanbatu, U.M., 2009. Perkembangan Dataran Pantai (Coastal Plain) Daerah Kendal Provinsi Jawa Tengah. Jurnal Sumber Daya Geologi, 19(4): 225 - 237.

Nugroho, S.H dan A. Basit., 2014. Sebaran Sedimen Berdasarkan Analisis Ukuran Butir di Teluk Weda, Maluku Utara. Jurnal Ilmu dan Teknologi Kelautan Tropis, 6(1): 229 -240.

Rifardi, O. K. dan Tomiyasu, T., 1998. Sedimentary Environments Based on Texture Surface Sediments and Sedimentation Rates in the South Yatsushiro (Sea), Soutwest Kyushu, Japan. Journal of the Sedimentological Society of Japan, (48): 67 - 84.

Sakka., M. Purba., I.W Nurjaya., H. Pawitan dan V.P Siregar., 2010. Transpormasi Gelombang di Sepanjang Pantai Delta Sungai Jeneberang, Makassar. Jurnal Ilmu Kelautan dan Perikanan, 20(2): $36-48$.

Sanjoto, T.B., S. Anggoro dan A. Hartoko., 2012. Kajian Perubahan Spasial Garis Pantai sebagai Zonasi Tata Ruang Pesisir (Studi Kasus Pesisir Kabupaten Kendal). Tata Loka, 14(1): 1 - 12.

Siregar, C.R.E., G. Handoyo dan A. Rifai., 2014. Studi Pengaruh Faktor Arus dan Gelombang Terhadap Sebaran Sedimen Dasar di Perairan Pelabuhan Kaliwungu Kendal. Jurnal Oseanografi, 3(3): 338 346.

Siswanto, A.D., 2007. Studi Aspek Geologi di Perairan Delta Bodri, Kabupaten Kendal. Embryo, 4(2): $114-123$.

Srijati, S., B. Rochaddi dan S. Widada., 2017. Analisis Laju Sedimentasi di Perairan Muara Sungai Waridin Kabupaten Kendal. Jurnal Oseanografi, 6(1): 246 - 253.

Stewart, H.B., 1958. Sedimentary Reflection on Depositional Environment, in San Mignellagoon, Baju California, Mexico. Bulletin of the American Association of Petroleum Geologists,11(42): 2567 2618.

Supriyadi, A., S. Widada dan H. Setiyono., 2014. Pemetaan Batimetri untuk Alur Pelayaran Pelabuhan Penyeberangan Mororejo Kabupaten Kendal. Jurnal Oseanografi, 3(2): 284 - 293.

Triatmodjo, B., 1999. Teknik Pantai. Beta Offset, Yogyakarta.

Wijaya, Y.D., D.F Atmaji., Sriyana dan F. Kistiani. 2014. Rekayasa Nilai Renaturalisasi Sungai Bodri Lama Terhadap Sungai Pecut, Kabupaten Kendal. Jurnal Karya Teknik Sipil, 3(3): 552 - 563. 
Wisha, U.J., W.A. Gemilang., G.A., Rahmawan dan G. Kusumah., 2017. Pola Sebaran Sedimen Dasar Berdasarkan Karakteristik Morfologi dan Hidro-Oseanografi Menggunakan Model Interpolasi dan Simulasi Numerik di Perairan Utara Pulau Simeuluecut. Jurnal Kelautan, 10(1): 29 - 40.

\section{LAMPIRAN}

Tabel 2. Hasil Perhitungan Parameter Statistik Ukuran Butir Sedimen

\begin{tabular}{|c|c|c|c|c|c|c|c|c|}
\hline \multirow{2}{*}{$\begin{array}{l}\text { Nomor } \\
\text { Sampel }\end{array}$} & \multirow[t]{2}{*}{ Mean } & \multirow{2}{*}{$\begin{array}{c}\text { Jenis } \\
\text { Sedimen }\end{array}$} & \multicolumn{2}{|r|}{ Sortasi } & \multicolumn{2}{|c|}{ Skewness } & \multicolumn{2}{|c|}{ Kurtosis } \\
\hline & & & Nilai & Klasifikasi & Nilai & Klasifikasi & Nilai & Klasifikasi \\
\hline 1 & 8.059 & Lanau & 0.035 & Terpilah Sangat Baik & -0.002 & Menceng simetris & 0.738 & Platykurtik \\
\hline 2 & 1.360 & Pasir & 0.300 & Terpilah Sangat Baik & -0.133 & Menceng kasar & 1.026 & Mesokurtik \\
\hline 3 & 8.058 & Lanau & 0.036 & Terpilah Sangat Baik & -0.002 & Menceng simetris & 0.738 & Platykurtik \\
\hline 4 & 8.058 & Lanau & 0.036 & Terpilah Sangat Baik & -0.002 & Menceng simetris & 0.738 & Platykurtik \\
\hline 5 & 8.059 & Lanau & 0.035 & Terpilah Sangat Baik & -0.002 & Menceng simetris & 0.738 & Platykurtik \\
\hline 6 & 8.059 & Lanau & 0.035 & Terpilah Sangat Baik & -0.002 & Menceng simetris & 0.558 & Platykurtik \\
\hline 7 & 8.058 & Lanau & 0.036 & Terpilah Sangat Baik & -0.002 & Menceng simetris & 0.738 & Platykurtik \\
\hline 8 & 8.059 & Lanau & 0.036 & Terpilah Sangat Baik & -0.002 & Menceng simetris & 0.738 & Platykurtik \\
\hline 9 & 8.059 & Lanau & 0.036 & Terpilah Sangat Baik & -0.002 & Menceng simetris & 0.738 & Platykurtik \\
\hline 10 & 8.059 & Lanau & 0.035 & Terpilah Sangat Baik & -0.002 & Menceng simetris & 0.738 & Platykurtik \\
\hline 11 & 8.059 & Lanau & 0.036 & Terpilah Sangat Baik & -0.002 & Menceng simetris & 0.738 & Platykurtik \\
\hline 12 & 8.059 & Lanau & 0.035 & Terpilah Sangat Baik & -0.002 & Menceng simetris & 0.738 & Platykurtik \\
\hline 13 & 8.059 & Lanau & 0.035 & Terpilah Sangat Baik & -0.002 & Menceng simetris & 0.738 & Platykurtik \\
\hline 14 & 8.059 & Lanau & 0.035 & Terpilah Sangat Baik & -0.002 & Menceng simetris & 0.738 & Platykurtik \\
\hline 15 & 8.059 & Lanau & 0.035 & Terpilah Sangat Baik & -0.002 & Menceng simetris & 0.738 & Platykurtik \\
\hline 16 & 8.059 & Lanau & 0.035 & Terpilah Sangat Baik & -0.002 & Menceng simetris & 0.738 & Platykurtik \\
\hline 17 & 8.059 & Lanau & 0.035 & Terpilah Sangat Baik & -0.002 & Menceng simetris & 0.738 & Platykurtik \\
\hline 18 & 8.059 & Lanau & 0.035 & Terpilah Sangat Baik & -0.002 & Menceng simetris & 0.738 & Platykurtik \\
\hline 19 & 8.059 & Lanau & 0.035 & Terpilah Sangat Baik & -0.002 & Menceng simetris & 0.738 & Platykurtik \\
\hline 20 & 8.059 & Lanau & 0.035 & Terpilah Sangat Baik & -0.002 & Menceng simetris & 0.738 & Platykurtik \\
\hline 21 & 8.059 & Lanau & 0.036 & Terpilah Sangat Baik & -0.002 & Menceng simetris & 0.738 & Platykurtik \\
\hline 22 & 8.059 & Lanau & 0.035 & Terpilah Sangat Baik & -0.002 & Menceng simetris & 0.738 & Platykurtik \\
\hline 23 & 8.059 & Lanau & 0.035 & Terpilah Sangat Baik & -0.002 & Menceng simetris & 0.738 & Platykurtik \\
\hline 24 & 8.059 & Lanau & 0.035 & Terpilah Sangat Baik & -0.002 & Menceng simetris & 0.738 & Platykurtik \\
\hline 25 & 8.059 & Lanau & 0.035 & Terpilah Sangat Baik & -0.002 & Menceng simetris & 0.738 & Platykurtik \\
\hline 26 & 8.059 & Lanau & 0.035 & Terpilah Sangat Baik & -0.002 & Menceng simetris & 0.738 & Platykurtik \\
\hline 27 & 8.059 & Lanau & 0.035 & Terpilah Sangat Baik & -0.002 & Menceng simetris & 0.738 & Platykurtik \\
\hline 28 & 8.059 & Lanau & 0.035 & Terpilah Sangat Baik & -0.002 & Menceng simetris & 0.738 & Platykurtik \\
\hline 29 & 8.059 & Lanau & 0.035 & Terpilah Sangat Baik & -0.002 & Menceng simetris & 0.738 & Platykurtik \\
\hline 30 & 8.059 & Lanau & 0.035 & Terpilah Sangat Baik & -0.002 & Menceng simetris & 0.738 & Platykurtik \\
\hline 31 & 8.059 & Lanau & 0.035 & Terpilah Sangat Baik & -0.002 & Menceng simetris & 0.738 & Platykurtik \\
\hline 32 & 8.059 & Lanau & 0.035 & Terpilah Sangat Baik & -0.002 & Menceng simetris & 0.738 & Platykurtik \\
\hline 33 & 8.059 & Lanau & 0.036 & Terpilah Sangat Baik & -0.002 & Menceng simetris & 0.738 & Platykurtik \\
\hline 34 & 8.059 & Lanau & 0.035 & Terpilah Sangat Baik & -0.002 & Menceng simetris & 0.738 & Platykurtik \\
\hline 35 & 8.059 & Lanau & 0.035 & Terpilah Sangat Baik & -0.002 & Menceng simetris & 0.738 & Platykurtik \\
\hline 36 & 8.059 & Lanau & 0.035 & Terpilah Sangat Baik & -0.002 & Menceng simetris & 0.738 & Platykurtik \\
\hline 37 & 8.059 & Lanau & 0.035 & Terpilah Sangat Baik & -0.002 & Menceng simetris & 0.738 & Platykurtik \\
\hline 38 & 8.059 & Lanau & 0.035 & Terpilah Sangat Baik & -0.002 & Menceng simetris & 0.738 & Platykurtik \\
\hline
\end{tabular}




\begin{tabular}{|c|c|c|c|c|c|c|c|c|}
\hline 39 & 8.059 & Lanau & 0.035 & Terpilah Sangat Baik & -0.002 & Menceng simetris & 0.738 & Platykurtik \\
\hline 40 & 8.059 & Lanau & 0.035 & Terpilah Sangat Baik & -0.002 & Menceng simetris & 0.738 & Platykurtik \\
\hline 41 & 8.059 & Lanau & 0.036 & Terpilah Sangat Baik & -0.002 & Menceng simetris & 0.738 & Platykurtik \\
\hline 42 & 1.182 & Pasir & 0.778 & Terpilah Sedang & 0.022 & Menceng simetris & 2.389 & $\begin{array}{c}\text { Sangat } \\
\text { Leptokurtik }\end{array}$ \\
\hline 43 & 8.059 & Lanau & 0.035 & Terpilah Sangat Baik & -0.002 & Menceng simetris & 0.738 & Platykurtik \\
\hline 44 & 8.059 & Lanau & 0.035 & Terpilah Sangat Baik & -0.002 & Menceng simetris & 0.738 & Platykurtik \\
\hline 45 & 8.059 & Lanau & 0.035 & Terpilah Sangat Baik & -0.002 & Menceng simetris & 0.738 & Platykurtik \\
\hline 46 & 0.273 & Pasir & 0.949 & Terpilah Sangat Baik & -0.007 & Menceng simetris & 0.626 & Sangat Platikurtik \\
\hline 47 & 1.128 & Pasir & 1.351 & Terpilah Buruk & -0.022 & Menceng simetris & 0.642 & Sangat Platikurtik \\
\hline 48 & 0.235 & Pasir & 0.903 & Terpilah Cukup & -0.047 & Menceng simetris & 0.569 & Sangat Platikurtik \\
\hline 49 & 0.693 & Pasir & 0.927 & Terpilah Cukup & -0.022 & Menceng simetris & 0.698 & Platykurtik \\
\hline 50 & 0.307 & Pasir & 1.255 & Terpilah Buruk & 0.014 & Menceng simetris & 0.724 & Platykurtik \\
\hline 51 & 0.440 & Pasir & 1.070 & Terpilah Buruk & 0.047 & Menceng simetris & 0.735 & Platykurtik \\
\hline 52 & 0.409 & Pasir & 1.104 & Terpilah Buruk & 0.030 & Menceng simetris & 0.764 & Platykurtik \\
\hline 53 & 0.654 & Pasir & 1.011 & Terpilah Buruk & -0.083 & Menceng simetris & 0.702 & Platykurtik \\
\hline 54 & 0.630 & Pasir & 0.970 & Terpilah Sedang & -0.056 & Menceng simetris & 0.657 & Platykurtik \\
\hline 55 & 1.364 & Pasir & 0.637 & Terpilah cukup baik & 0.256 & Menceng halus & 2.675 & $\begin{array}{c}\text { Sangat } \\
\text { Leptokurtik }\end{array}$ \\
\hline 56 & 1.391 & Pasir & 0.357 & Terpilah Baik & -0.167 & Menceng kasar & 1.156 & Leptokurtik \\
\hline 57 & 1.335 & Pasir & 0.349 & Terpilah Sangat Baik & 0.249 & Menceng halus & 1.413 & Leptokurtik \\
\hline 58 & 1.548 & Pasir & 0.545 & Terpilah Baik & 0.115 & Menceng simetris & 1.297 & Leptokurtik \\
\hline 59 & 1.538 & Pasir & 0.630 & Terpilah cukup baik & 0.218 & Menceng halus & 1.685 & $\begin{array}{c}\text { Sangat } \\
\text { Leptokurtik }\end{array}$ \\
\hline 60 & 1.857 & Pasir & 0.785 & Terpilah Cukup & 0.102 & Menceng halus & 1.436 & $\begin{array}{c}\text { Sangat } \\
\text { Leptokurtik }\end{array}$ \\
\hline 61 & 1.826 & Pasir & 0.539 & Terpilah cukup baik & -0.047 & Menceng simetris & 0.760 & Platykurtik \\
\hline 62 & 1.075 & Pasir & 0.704 & Terpilah Cukup & 0.071 & Menceng simetris & 2.292 & $\begin{array}{c}\text { Sangat } \\
\text { Leptokurtik }\end{array}$ \\
\hline 63 & 0.766 & Pasir & 0.893 & Terpilah Cukup & -0.012 & Menceng simetris & 0.809 & Platykurtik \\
\hline 64 & 0.963 & Pasir & 0.789 & Terpilah Cukup & 0.010 & Menceng simetris & 2.248 & $\begin{array}{c}\text { Sangat } \\
\text { Leptokurtik }\end{array}$ \\
\hline 65 & 1.343 & Pasir & 0.535 & Terpilah cukup baik & 0.230 & Menceng halus & 2.284 & $\begin{array}{c}\text { Sangat } \\
\text { Leptokurtik }\end{array}$ \\
\hline
\end{tabular}

